\title{
Ion Flotation of Ytterbium Water-Salt Systems-An Innovative Aspect of the Modern Industry
}

\author{
Olga Leonidovna Lobacheva (iD \\ General Chemistry Department, Saint Petersburg Mining University, 199106 Saint Petersburg, Russia; \\ Olga-59@yandex.ru; Tel.: +7-9043304994
}

check for updates

Citation: Lobacheva, O.L. Ion Flotation of Ytterbium Water-Salt Systems-An Innovative Aspect of the Modern Industry. Water 2021, 13, 3493. https://doi.org/10.3390/ w13243493

Academic Editor: Avi Ostfeld

Received: 3 November 2021

Accepted: 2 December 2021

Published: 8 December 2021

Publisher's Note: MDPI stays neutral with regard to jurisdictional claims in published maps and institutional affiliations.

Copyright: (C) 2021 by the author. Licensee MDPI, Basel, Switzerland. This article is an open access article distributed under the terms and conditions of the Creative Commons Attribution (CC BY) license (https:// creativecommons.org/licenses/by/ $4.0 /)$.

\begin{abstract}
Considering the ever-increasing role of rare-earth elements (REE) in the modern hi-tech field, their effective use has tremendous significance, although the production process is inevitably linked to the large volumes of industrial ammonia effluents and heavy metal wastes. In the process of metallurgical separation of metals, the emission of large volumes of noxious gases and radioactive substances is inevitable. Lean technogenic raw material processing is sensible under the condition of the development of non-waste technology. The lack of competent regulations governing the disposal of waste containing REE has an impact on adjacent territories, accumulating in water bodies and, as a result, in the human body. Such an impact cannot pass without a trace, however, the ambiguity of opinions in the scientific community regarding the toxic effects of REE on living organisms determines the relevance of a more detailed study of this issue. The study of ytterbium ions removal from aqueous standard test solutions by the adsorptive bubble method-ion flotation-was conducted. The experiments showed that by using the ion flotation method, the maximum removal of ytterbium (III) was achieved at $\mathrm{pH}=8.30$. It was shown that ytterbium (+3) distribution coefficients as a function of aqueous phase $\mathrm{pH}$ value in the process of ion flotation with sodium dodecyl sulphate were derived. The comparison of values of removal $\mathrm{pH}$ with those of hydrate formation $\mathrm{pH}$ allowed to conclude that ytterbium floate as basic dihydroxoytterbium dodecyl sulphate $\mathrm{Yb}(\mathrm{OH})_{2}\left(\mathrm{C}_{12} \mathrm{H}_{25} \mathrm{OSO}_{3}\right)$.
\end{abstract}

Keywords: contamination in environmental media; ion flotation; rare-earth elements; removal

\section{Introduction}

The development of REE mineral deposits provokes the leakage of pollutants that pose a danger to human life and health and severely damages the environment. The rectification of pollution consequences and environmental rehabilitation of territories is topical in the present-day world for REE mining and production areas [1]. Among the relevant areas of detailed study of the effect of REE on living organisms, the following can be distinguished: the widespread and active use of REE in industry necessitates the study of their physicochemical properties in order to prevent them from entering the environment and living organisms with disposal of hazardous waste containing REE [2-5]. In particular, to conduct ecological and geochemical zoning and allocation of territories with the presence of anomalies (the presence of REE), Tomsk Polytechnic University conducted studies of the ratio of lanthanum and cerium. The choice of such a material was due to the fact that lanthanum and cerium are light REE, and it is they that accumulate in organ tissues and blood plasma, while heavy REE are concentrated mainly in the skeleton. According to the assumptions put forward, toxic elements enter the human body through drinking water, are absorbed into the blood from the gastrointestinal tract, and then enter the thyroid gland. Part of the REE is able to linger in the lungs, which can lead to the development of chronic nonspecific inflammatory phenomena such as bronchitis, bronchiolitis, alveolitis, and pneumonia [6]. The presence of polar points of view on the effects of REE on the human body serves as the basis for studying this area [7-11].

This paper studies the possibility of lanthanide ion removal from diluted aqueous solutions (as exemplified by yttrium ions) by the ion flotation method using SDS as the 
collector agent [12]. Russia has no less than $20 \%$ of the world's REE reserves, but the volume of extraction of raw materials is approximately $2 \%$ of the world's extraction volume [13-17].

To identify the process mechanisms of metal cation removal and separation by the ion flotation method, it is necessary to know know the $\mathrm{pH}$ of metal hydroxo complexes formation and the $\mathrm{pH}$ of hydrate formation, calculated based on the Gibbs energies of hydroxo complexes and metal hydroxides formation (Table 1). The $\mathrm{pH}$ value of $\mathrm{Yb}(\mathrm{OH})^{2+}$ hydroxo complexes formation can be calculated based on the expression for instability constants [18].

Table 1. Thermodynamic quantities-Gibbs energy of formation of hydrated ions $-\Delta_{f} G_{298}^{0}$ and hydration enthalpy $\Delta_{h y d r} H$ of $\operatorname{Ln}^{3+}$ aq cations [18].

\begin{tabular}{ccc}
\hline Element & $-\Delta_{f} G_{298}^{0}\left(\operatorname{Ln} 3^{+}{ }_{\text {aq }}\right), \mathbf{k J} / \mathbf{m o l}$ & $-\Delta_{\text {hydr }} H_{\left(\mathbf{L n 3}^{+}{ }_{\text {aq }}\right), \mathbf{k J} / \mathbf{m o l}}$ \\
\hline $\mathrm{Tb}$ & 664.18 & 3570 \\
\hline $\mathrm{Dy}$ & 660.92 & 3600 \\
\hline $\mathrm{Ho}$ & 685.89 & 3650 \\
\hline $\mathrm{Er}$ & 670.93 & 3680 \\
\hline $\mathrm{Tm}$ & 670.08 & 3700 \\
\hline $\mathrm{Yb}$ & 644.43 & 3710 \\
\hline $\mathrm{Lu}$ & 631.45 & 3750 \\
\hline
\end{tabular}

A special feature of Russian raw material sources is the low REE content and complex chemical and mineralogical composition. The processing of such raw materials is unprofitable [19-27]. Furthermore, ore mined at the Kola peninsula (a fairly developed Arctic region in Russia) is used for production of up to 25 concentrates that are different in terms of their composition and properties [28].

According to data [21], the ion flotation method was used for removal of rare-earth and radioactive metal cations from residential wastewaters. Additionally, this method was used for removal of oil admixtures and petroleum contained in the system from wastewaters [22]. The removal ratio of ion flotation when removing metal cations from the solutions of lean technogenic raw materials achieved 100\% [29-32].

The main aim is to show experimentally the possibility of extraction by ion flotation of ytterbium cations from dilute aqueous solutions and with thermodynamic calculations to confirm the shape of the extracted complex considered REE.

\section{Materials and Methods}

\subsection{Process Procedure}

According to literature data, an increase of process effectiveness because of valuable components extraction from production wastes is possible when using the ion flotation method in the mining industry $[18,19]$. It was assumed that the decrease of REE toxicity, and the risk of damaging the environment, is presumed. In $[18,19,21]$, the ion flotation method was offered for REE removal from apatite sulphuric acid processing products.

Ion flotation was conducted on a flotation machine (Figure 1) [30]. Two hundred milliliters of ytterbium nitrate solution with a concentration of $0.001 \mathrm{~mol} / \mathrm{L}$ and dry SDS were added to the cuvette. The process continued no more than $5 \mathrm{~min}$. The formed froth was broken by $5 \mathrm{~mL}$ of sulphuric acid solution with a concentration of $1 \mathrm{~mol} / \mathrm{L}$. The resulting froth pulp and the solution that remained in the cuvette were analyzed for REE content by using a method from [33] and for dodecyl sulphate ion content by the potentiometer method [30]. 


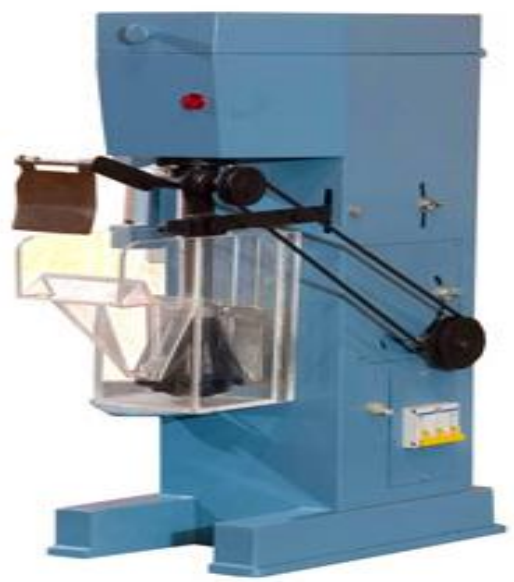

Figure 1. Flotation machine В-

\subsection{Equipment}

This paper studied the distribution of $\mathrm{Yb}^{3+}$ ions in solutions formed by standardized test solutions containing $\mathrm{Yb}^{3+}$ ions and a surfactant—sodium dodecyl sulphate (SDS). A flotation machine for ion flotation of lanthanide ions is shown in Figure 1. The critical concentration for micelle formation (CCM) of NaDS is $8 \times 10^{-3} \mathrm{~mol} \cdot \mathrm{kg}^{-1}$ at $20^{\circ} \mathrm{C}$ [29].

\section{Experimental and Theoretical Results}

The results of ion flotation study of the solutions containing $\mathrm{Yb}^{3+}$ and $\mathrm{DS}^{-}$are shown in Table 2. Ytterbium cation distribution coefficients between water and organic phases was determined by the formula: $K_{\text {distribution }}=C_{o r g} / C_{a q}$.

Table 2. The results of the experimental study of ion flotation in $\mathrm{Yb}^{+3}$ solutions.

\begin{tabular}{|c|c|c|c|}
\hline $\mathrm{pH}$ & {$\left[\mathrm{Yb}^{3+}\right]_{\mathrm{aq}} \cdot 10^{4} \mathrm{~mol} / \mathrm{L}$} & {$\left[\mathrm{Yb}^{3+}\right]_{\mathrm{org}} \cdot 10^{3} \mathrm{~mol} / \mathrm{L}$} & $\begin{array}{c}\text { Distribution } \\
\text { Coefficient }\end{array}$ \\
\hline 1.86 & 6.59 & 1.56 & 2.3 \\
\hline 3.00 & 3.40 & 2.03 & 5.9 \\
\hline 3.50 & 3.43 & 2.33 & 6.8 \\
\hline 4.01 & 2.62 & 2.37 & 9.1 \\
\hline 4.60 & 2.73 & 2.24 & 8.2 \\
\hline 5.03 & 2.23 & 2.21 & 9.5 \\
\hline 5.50 & 2.69 & 2.48 & 9.2 \\
\hline 6.00 & 1.79 & 2.46 & 13.8 \\
\hline 6.40 & 0.25 & 2.40 & 95.4 \\
\hline 7.06 & 0.07 & 1.85 & 281.3 \\
\hline 7.38 & 0.05 & 1.96 & 365.3 \\
\hline 8.30 & 0.06 & 2.27 & 403.7 \\
\hline 9.10 & 0.06 & 2.03 & 318.4 \\
\hline
\end{tabular}

From the experimental data shown in the table, we could conclude that $\mathrm{Yb}^{3+}$ removal did not practically take place in acidic mediums. With the increase of $\mathrm{pH}$ value from 4.01 to 5.50, the distribution coefficient value was just over 9.0. Not surprisingly, in this $\mathrm{pH}$ range, neutral and basic ytterbium dodecyl sulphates $\mathrm{Yb}\left(\mathrm{C}_{12} \mathrm{H}_{25} \mathrm{OSO}_{3}\right)_{3}$ and $\mathrm{Yb}(\mathrm{OH})\left(\mathrm{C}_{12} \mathrm{H}_{25} \mathrm{OSO}_{3}\right)_{2}$ float. From the resulting experimental data, it was clear that at $\mathrm{pH}$ exceeding 6.00, the distribution coefficient increased rapidly. This value was lower than 
the $\mathrm{pH}$ value of hydrate formation that was previously determined by us. Consequently, in the $\mathrm{pH}$ range satisfying the maximum removal, ytterbium floats in the hydroxide form with the admixture of neutral and basic dodecyl sulphate.

\section{Discussion}

According to the literature data, in the process of ion flotation of metal cations, the increase in removal occurs in the $\mathrm{pH}$ range of hydrate formation [29,30], that is, metal cations are observed passing into froth as hydroxides. In a number of studies $[1,15,18]$ it was discovered that to identify the mechanism of metal cation removal by ion flotation, the $\mathrm{pH}$ of metal hydroxo complexes and $\mathrm{pH}$ of hydrate formation need to be known. The $\mathrm{pH}$ value of $\mathrm{Yb}(\mathrm{OH})^{2+}$ hydroxo complexes formation is calculated based on the expression for instability constant.

According to the experimental results, the titration curve was plotted as shown in Figure 2.

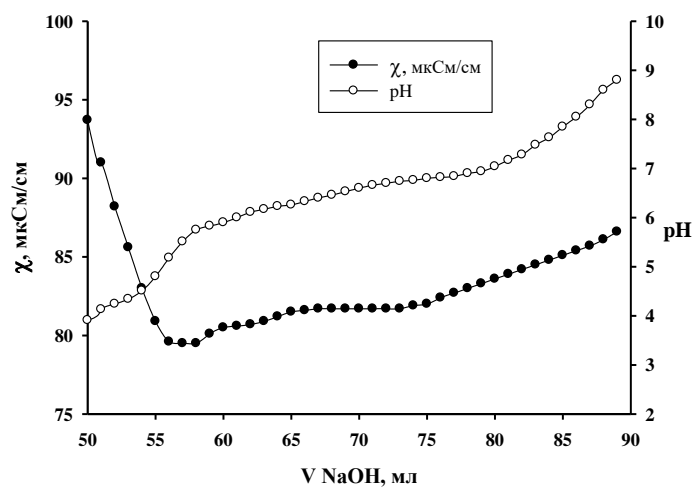

Figure 2. Specific electrical conductivity of $\mathrm{Yb}(\mathrm{NO})_{3}$ solution and $\mathrm{pH}$ as a function of $\mathrm{NaOH}$ solution volume in the course of conductometric titration.

The Gibbs energy values of $\mathrm{Yb}(\mathrm{OH})_{3}$ formation, specified in the database under the editorship of V.P. Glushko [34] $-1268.59 \pm 3.77 \mathrm{~kJ} / \mathrm{mol}$ and in the handbook [35], agreed poorly. In the database [36], this value is missing. The Gibbs energy values of $\mathrm{Yb}(\mathrm{OH})^{2+}$ formation $-832.62 \pm 3.77 \mathrm{~kJ} / \mathrm{mol}$ in the database [34] and -836.29 in [36] agreed satisfactorily, however, they were at odds with the $\mathrm{pH}$ of hydrate formation. Calculated by the value [34], $\mathrm{pH}_{\text {compl }} 7.7$ was notably higher than $\mathrm{pH}_{\text {hydr }}$, which was 6.40, while the formation of hydroxo complexes should precede hydroxide sedimentation and take place at lower $\mathrm{pH}$ values. Because of inconsistency of values available in the literature data, an evaluation of $\mathrm{pH}$ of complex formation and hydrate formation by conductometric titration method was attempted. Titration results were reproduced three times to confirm their reliability. The calculated values are shown in Table 3. The following areas on the conductometric titration curves are marked out.

Table 3. Thermodynamic characteristics of ytterbium hydroxo compounds.

\begin{tabular}{|c|c|c|c|c|}
\hline Compound & $\Delta_{f} G_{298}^{0}, \mathbf{k J} \cdot \mathbf{m o l}^{-1}$ & $\Delta_{s} G_{298}^{0}\left(\Delta_{c o m p l} G_{298}^{0}\right), \mathbf{k J} \cdot \mathrm{mol}^{-1}$ & $L\left(K_{n, z}\right)$ & $\begin{array}{c}p H_{h y d r} \\
\left(p H_{c o m p l}\right)\end{array}$ \\
\hline $\mathrm{Yb}(\mathrm{OH})_{3}$ & $-1266.74 \pm 3.90$ & $-149.81 \pm 2.57$ & $5.66 \pm 4.50) \times 10^{-27}$ & 6.56 \\
\hline $\mathrm{Yb}(\mathrm{OH})^{2+}$ & $-849.17 \pm 3.03$ & $-47.39 \pm 0.77$ & $4.99 \pm 1.33) \times 10^{-9}$ & 5.47 \\
\hline $\mathrm{Yb}(\mathrm{OH})_{2}^{+}$ & $-1050.47 \pm 3.22$ & $-43.95 \pm 1.35$ & $1.61 \pm 0.45) \times 10^{-8}$ & 6.08 \\
\hline
\end{tabular}

1. Up to $60 \mathrm{~mL}$ of titrant-a linear drop of specific electrical conductivity was observed, accompanied with a $\mathrm{pH}$ rise because of the nitric acid neutralization by alkali. This section was not mandatory but can be added to the manuscript if the discussion is unusually long or complex. 
2. From 62 to $67 \mathrm{~mL}$ of titrant-weak linear growth of specific electrical conductivity was observed, which showed the binding of added hydroxyl anions into a poorly dissociated compound with sodium nitrate accumulation in the solution. Since the formation of hydroxides was not observed (optical density of solutions did not change), this part handled the formation of hydroxo complexes. By the quantity of milliequivalents of alkali spent in this part, we defined that the process flows until the formation of $\mathrm{Yb}(\mathrm{OH})^{2+}$ monohydroxo complex. $\mathrm{pH}=5.50$, conforming to the beginning of this part of the titration curve, was taken as the $\mathrm{pH}$ of complex formation over the first stage of $\mathrm{pH}_{\text {compl }}$.

3. Upon the completion of complex formation over the first stage, a surge on the relationship of specific electrical conductivity as a function of titrant volume was observed at 67-68 mL, conditioned by high equivalent conductivity of the added hydroxyl anions. Next, from 68 to $74 \mathrm{~mL}$ of titrant, there was an almost horizontal part of the titration curve, attributed to $\mathrm{Yb}(\mathrm{OH})_{2}{ }^{+}$dihydroxo complexes formation. $\mathrm{pH}=6.00$ conformed to the beginning of complex formation over the second stage.

4. At the titrant volume of $74-75 \mathrm{~mL}$, a new electrical conductivity surge with a transition to a horizontal part of the titration curve at the titrant volume of $75-86 \mathrm{~mL}$ was observed. This part of the titration curve corresponded to hydroxide sedimentation in accordance with the reaction: $\mathrm{Yb}(\mathrm{OH})_{2}{ }^{+}+\mathrm{OH}^{-}=\mathrm{Yb}(\mathrm{OH})_{3}$. The latter was observed visually and confirmed by an increase in the optical density of solutions. The $\mathrm{pH}$ value of hydrate formation was 6.50 .

5. Further on the titration curve, the near-linear growth of specific electrical conductivity because of excess alkali was observed. The solubility product of ytterbium hydroxide was calculated according to the formula:

$$
L=\left[Y b^{3+}\right]\left(10^{p H_{\text {hydr }}-14}\right)^{3} \cdot \gamma_{ \pm}
$$

where ytterbium cation concentration considering aliquot dilution during the titration up to the volume of $85 \mathrm{~mL}$ was $1.46 \times 10^{-4} \mathrm{~mol} \cdot \mathrm{kg}^{-1}$ in the experiment. Ionic strength was calculated considering nitric acid, added to establish an initial $\mathrm{pH}$ value of 3.07, and alkali, added during the titration. The value of $3.64 \times 10^{-3} \mathrm{~mol} \cdot \mathrm{kg}^{-1}$ was achieved. The medium ion activity coefficient of ytterbium nitrate was taken equal to the activity coefficient of lanthanum chloride under this ionic strength -0.81 [19]. The Gibbs energy of hydroxide formation was calculated according to the equation:

$$
\Delta_{\mathrm{f}} G_{298}^{0}\left\{Y b(\mathrm{OH})_{3}\right\}=\Delta_{f} G_{298}^{0}\left\{Y b_{a q}^{3+}\right\}+3 \Delta_{f} G_{298}^{0}\left\{O H_{a q}^{-}\right\}+R T \ln L
$$

The standard Gibbs energy value of ytterbium ion formation in an aqueous solution was accepted according to the database [34] as $-644.88 \pm 2.93 \mathrm{~kJ} / \mathrm{mol}$. The resulting values are shown in Table 3. At the same place, the Gibbs energy values of ytterbium $\Delta_{S} G_{298}^{0}$ hydroxide dissolution and Gibbs energies of complex formation $\Delta_{\text {compl }} G_{298}^{0}$ over ytterbium $\Delta_{S} G_{298}^{0}$ hydroxide dissolution and Gibbs energies of complex formation $\Delta_{\text {compl }} G_{298}^{0}$ over the following stages:

$$
\begin{gathered}
\mathrm{Yb}^{3+}+\mathrm{OH}^{-} \leftrightarrow \mathrm{Yb}(\mathrm{OH})^{2+} \\
\mathrm{Yb}(\mathrm{OH})^{2+}+\mathrm{OH}^{-} \leftrightarrow \mathrm{Yb}(\mathrm{OH})_{2}{ }^{+} \\
\mathrm{Yb}(\mathrm{OH})_{2}{ }^{+}+\mathrm{OH}^{-}
\end{gathered}
$$

The obtained Gibbs energy value of ytterbium hydroxide formation agreed well with the database [34], where the value of $-1268.59 \pm 3.77 \mathrm{~kJ} / \mathrm{mol}$ is specified. The Gibbs energy value of ytterbium monohydroxo complex formation differed significantly from the values of $-832.62 \pm 3.77 \mathrm{~kJ} / \mathrm{mol}$ and $-836.29 \mathrm{~kJ} / \mathrm{mol}$ specified in the databases [34-37]. We calculated the $\mathrm{Yb}(\mathrm{OH})^{2+}$ hydroxo complex instability constant according to data from [34]. The gotten value of $3.96 \times 10^{-6}$ corresponded to the $\mathrm{pH}$ of complex formation onset that 
was 7.7. However, according to our data, this value was significantly higher than the $\mathrm{pH}$ of hydrate formation, which is contradictory. Data for ytterbium $\mathrm{Yb}(\mathrm{OH})_{2}{ }^{+}$dihydroxo complex formation was obtained for the first time.

\section{Conclusions}

The conductometric titration method was used to determine Gibbs energy values of ytterbium (3+) hydroxide, mono- and dihydroxo complexes formation, which were $-1266.74 \pm 3.90 \mathrm{~kJ} \cdot \mathrm{mol}^{-1},-849.17 \pm 3.03 \mathrm{~kJ} \cdot \mathrm{mol}^{-1}$ and $-1050.47 \pm 3.22 \mathrm{~kJ} \cdot \mathrm{mol}^{-1}$, respectively. Data for ytterbium $\mathrm{Yb}(\mathrm{OH})^{2+}$ dihydroxo complex formation was obtained for the first time. Interesting experimental results were obtained-using the ion flotation method, the maximum removal of ytterbium (III) was achieved at $\mathrm{pH}=8.30$. Ytterbium (3+) distribution coefficients as a function of aqueous phase $\mathrm{pH}$ value in the process of ion flotation with sodium dodecyl sulphate were derived. The comparison of values of removal $\mathrm{pH}$ with those of hydrate formation $\mathrm{pH}$ allowed to conclude that ytterbium floats as basic dihydroxoytterbium dodecyl sulphate $\mathrm{Yb}(\mathrm{OH})_{2}\left(\mathrm{C}_{12} \mathrm{H}_{25} \mathrm{OSO}_{3}\right)$.

\section{Patents}

Lobacheva, O.L.; Dzhevaga, N.V. Method of separation of holmium (III) and cerium (III) by anionic surfactant from an aqueous solution of their nitrates. RU No 2735017 C1, 27 October 2020.

Funding: The study was carried out at the expense of a subsidy for the implementation of the state task in the field of scientific activity for 2021 No. FSRW-2020-0014.

Institutional Review Board Statement: Not applicable.

Informed Consent Statement: Not applicable.

Data Availability Statement: The experimental data proposed in the article were obtained for the first time and have not been published before. Similar data were previously presented in the following scientific publications: 1. Lobacheva, O.L.; Dzhevaga, N.V.; Danilov, A.S. Understanding the regularities of recovering non-ferrous and rare earth metals from standard test solutions by flotation and solvent sublation. Non-Ferr. Met. 2020, V.10, 14-19. https://doi.org/10.17580/tsm.20 20.10.02; 2. Dzhevaga, N.; Lobacheva, O. Reduction in technogenic burden on the environment by flotation recovery of rare earth elements from diluted industrial solutions. J. Appl. Sci. 2021, 11, 7452.

Acknowledgments: The author expresses thanks to Natalia Dzhevaga (Geo-ecology department of Saint Petersburg Mining University) for her help in preparation of this paper's manuscript.

Conflicts of Interest: The author declares no conflict of interest.

\section{References}

1. Dzhevaga, N.; Lobacheva, O. Reduction in technogenic burden on the environment by flotation recovery of rare earth elements from diluted industrial solutions. J. Appl. Sci. 2021, 11, 7452. [CrossRef]

2. Narkovich, D.V.; Baranovskaya, N.V.; Koval, E.V.; Korogod, N.P. Influence of technogenesis on forming element composition of children's hair. Bull. Tomsk. Polytech. Univ. Geo Assets Eng. 2016, 327, 116-128.

3. Carneiro, M.F.H.; Moresco, M.; Chagas, G.R.; Oliveira Souza, V.C.; Rhoden, C.; Barbosa, F., Jr. Assessment of trace elements in scalp hair of a young urban population in Brazil. Biol. Trace Elem. Res. 2011, 143, 815-824. [CrossRef] [PubMed]

4. Pan, Y.; Li, H. Trace elements in scalp hair from potentially exposed individuals in the vicinity of the Bayan Obo mine in Baotou, China. Environ. Toxicol. Pharmacol. 2015, 40, 678-685. [CrossRef]

5. Gil, F; Hernandez, A.F. Toxicological importance of human bio-monitoring of metallic and metalloid elements in different biological samples. Food Chem. Toxicol. 2015, 80, 287-297. [CrossRef] [PubMed]

6. Popov, V.K.; Pasechnik, E.Y.; Protsenko, P.I.; Goncharov, O.Y. Rare earth element content in groundwater of tomsk water intake. Bull. Tomsk. Polytech. Univ. Geo Assets Eng. 2018, 329, 97-105.

7. Zabrecky, J.M.; Liu, X.-M.; Wu, Q.; Cao, C. Evidence of Anthropogenic Gadolinium in Triangle Area Waters, North Carolina, USA. Water 2021, 13, 1895. [CrossRef]

8. Ge, Q.; Xue, Z.G.; Chu, F. Rare Earth Element Distributions in Continental Shelf Sediment, Northern South China Sea. Water 2020, 12, 3540. [CrossRef] 
9. Liu, Y.; Li, C.; Omar, R.B.; Shi, X.; Zhang, H.; Faiz, N.N. Sediment Sources and Dispersion on the Western Sunda Shelf, Malay Peninsula, Southern South China Sea. Water 2021, 13, 2823. [CrossRef]

10. Litvinova, T. Yttrium and Lanthanides Metallurgy; Saint-Petersburg Mining University: Saint-Petersburg, Russia, $2012 ;$ p. 185.

11. Cheremisina, O.V.; Volkova, O.; Litvinova, T.E. Influence of anion nature on acid leaching of silicate minerals and solvent extraction of rare and rare-earth elements. Chem. Erde. 2020, 80, 125507. [CrossRef]

12. Sebba, F. Ion Flotation; Elsevier: Amsterdam, The Netherlands, 1965; p. 170.

13. Matveeva, V.; Danilov, A.; Pashkevich, M. Treatment of multi-tonnage manganese-containing waste water using vermiculite. J. Ecol. Eng. 2018, 19, 156-162. [CrossRef]

14. Strizhenok, A.V.; Ivanov, A.V. Monitoring of Air Pollution in the Area Affected by the Storage of Primary Oil Refining Waste. J. Ecol. Eng. 2021, 22, 60-67. [CrossRef]

15. Lutskiy, D.; Litvinova, T.; Ignatovich, A.; Fialkovskiy, I. Complex processing of phosphogypsum-A way of recycling dumps with reception of commodity production of wide application. J. Ecol. Eng. 2018, 19, 221-225. [CrossRef]

16. Goman, I.V.; Oblova, I.S. Analysis of companies' corporate social responsibility as a way to develop environmental ethics for students specialising in oil and gas activity. Int. Multidiscip. Sci. GeoConference Surv. Geol. Min. Ecol. Manag. SGEM 2018, 18, 11-18. [CrossRef]

17. Machevariani, M.M.; Alekseenko, A.V.; Bech, J. Complex characteristic of zircon from granitoids of the Verkhneurmiysky Massif (Amur region). Minerals 2021, 11, 86. [CrossRef]

18. Lobacheva, O.L.; Dzhevaga, N.V.; Danilov, A.S. Understanding the regularities of recovering non-ferrous and rare earth metals from standard test solutions by flotation and solvent sublation. Non-Ferr. Met. 2020, V.10, 14-19. [CrossRef]

19. Database of Chemicals and Compounds: "Chemical Database Schemix". Available online: http://www.schemix.ru/downloads. aspx (accessed on 11 February 2021).

20. Lokshin, E.P.; Kalinnikov, V.T.; Tareeva, O.A. Extraction of rare earth elements from industrial products and waste from processing of Khibiny apatite concentrate. Non-Ferr. Met. 2012, 21, 75-80.

21. Medyanik, N.L.; Chanturia, V.A.; Shadrunova, I.V. Quantum-chemical method for selection of a collecting agentto recover zinc and copper (II) cation sin flotation of mine waste waters. J. Min. Sci. 2012, 48, 167-176. [CrossRef]

22. Ramírez-Serrano, B.; Coello-Velazquez, A.L.; Bernardo, A.; Afif, E.; Menendez-Aguado, J.M. Recovery of copper-ion by flotation with potassium amylxanthate. Rev. Metal. 2012, 48, 254-263. [CrossRef]

23. Kazanskaya, L.F.; Smirnova, O.M.; Palomo, Á.; Pidal, I.M.; Romana, M. Supersulfated cement applied to produce lightweight concrete. Materials 2021, 14, 403. [CrossRef]

24. Romashev, A.; He, D.; Aleksandrova, T.; Nikolaeva, N. Technological typomorphic associations in caustobiolites and methods of their extraction. Metals 2021, 11, 121. [CrossRef]

25. Bazhin, V.Y.; Aleksandrova, T.A.; Kotova, E.L.; Suslov, A.P. A modern view of anomalies in the metal groups of the periodic system of D.I. Mendeleev. J. Min. Inst. 2019, 239, 520-527. [CrossRef]

26. Kurdiumov, V.R.; Timofeev, K.L.; Maltsev, G.I.; Lebed, A.B. Sorption of nickel (II) and manganese (II) ions from aqueous solutions. J. Min. Inst. 2020, 242, 209-217. [CrossRef]

27. Storozhenko, D.; Dryuchko, O.; Jesionowski, T.; Ivanytska, I. Some Physicochemical Aspects of the Preparatory Stages in the Formation of Self-cleaning Photocatalytic Active Coatings for Building Construction Materials. Lect. Notes Civ. Eng. 2020, 73, 285-301. [CrossRef]

28. Nikolaev, A.I.; Krivovichev, S.V. Kola Peninsula in solving problems of national arctic materials science. IOP Conf. Ser. Mater. Sci. Eng. 2019, 696, 012019. [CrossRef]

29. Lemlich, R. Adsorptive Bubble Separation Techniques; Academic Press: New York, NY, USA, 1972; p. 344.

30. Lobacheva, O.; Dzhevaga, N. Rare-earth elements recovery on the example of Europium (III) from lean technogenic raw materials. J. Ecol. Eng. 2017, 18, 122-126. [CrossRef]

31. Hoseinian, F.S.; Rezai, B.; Kowsari, E.; Chinnappan, A.; Ramakrishna, S. Synthesis and characterization of a novel nanocollector for the removal of nickel ions from synthetic wastewater using ion flotation. Sep. Purif. Technol. 2020, 240, 116639. [CrossRef]

32. Grieves, R.B.; Charewicz, W.R. Ion and colloid flotation of Ni, Co and Pt. Sep. Sci. 1975, 10, 77-92.

33. Savin, S.B. Arsenazo III; Atomizdat: Moscow, Russia, 1966; p. 265.

34. Glushko, V.P. (Ed.) Thermal Constants of Substances Handbook; Academy of Sciences: Moscow, Russia, 1978; Volume 2, p. 358.

35. Lidin, R.A.; Andreeva, A.A.; Molochko, A.V. Constants of Inorganic Substances; Begell House: Danbury, CT, USA, 2006.

36. HSC Chemistry OutoKumpu Research OY (ver. 4.1.); Pori, Finland. Available online: http:/ / www.chemistry-software.informer.com (accessed on 3 November 2021).

37. Ravdel, A.A.; Ponomareva, A.M. Guide of Physics-Chemical Quantities; Fedorov, I., Ed.; Scientific Research Publishing Inc.: Irvine, CA, USA, 2003; p. 240. 